$10-2017$

\title{
Genocide Studies and Corporate Social Responsibility: The Contemporary Case of the French National Railways (SNCF)
}

Sarah Federman

University of Baltimore

Follow this and additional works at: https://digitalcommons.usf.edu/gsp

\section{Recommended Citation}

Federman, Sarah (2017) "Genocide Studies and Corporate Social Responsibility: The Contemporary Case of the French National Railways (SNCF)," Genocide Studies and Prevention: An International Journal: Vol. 11: Iss. 2: 13-35.

DOI:

http://doi.org/10.5038/1911-9933.11.2.1390

Available at: https://digitalcommons.usf.edu/gsp/vol11/iss2/5

This Articles is brought to you for free and open access by the Open Access Journals at Digital Commons @ University of South Florida. It has been accepted for inclusion in Genocide Studies and Prevention: An International Journal by an authorized editor of Digital Commons @ University of South Florida. For more information, please contact digitalcommons@usf.edu. 


\section{Genocide Studies and Corporate Social Responsibility: The Contemporary Case}

of the French National Railways (SNCF)

\section{Acknowledgements}

Thank you to George Mason University and the Fondation pour la Mémoire de la Shoah for their financial support. 


\title{
Genocide Studies and Corporate Social Responsibility: The Contemporary Case of the French National Railways (SNCF)
}

\author{
Sarah Federman \\ George Mason University \\ Arlington, VA, USA
}

\begin{abstract}
Introduction
The revenues of transnational corporations increasingly exceed the GDPs of some of the countries in which they operate. Wal-Mart's revenue now exceeds the GDP of 170 countries, for example, and the trend is on the rise. ${ }^{1}$ The transnational nature of business also means any region with violent outbreaks has large market actors either participating in or suffering from the disruptions of violence-sometimes both. Violent outbreaks in Darfur, for example, cost the Chinese oil industry millions of dollars, as did the violence during the fall of Muammar Gaddafi in Libya. Long-term market actors often have much to lose during violence, but - of course-some profit tremendously in the interim. These relationships are complicated, shifting, and intertwined. This article argues for greater inclusion of market actors in genocide studies both to understand and respond to the complex roles these actors play in both participating in and interrupting mass atrocity.

This article defines market actors as any business, transnational or domestic, of any size and considers questions of both accountability and responsibility. Corporate accountability refers to the amends a market actor attempts in the aftermath of human rights violations. Responsibility refers to the activities and/or the ethos of the company to promote human betterment. The United Nation's Guiding Principles on Business and Human Rights address questions of both responsibility and accountability. The first two guiding principles consider prevention and the third, remedies. ${ }^{2}$
\end{abstract}

1. States' existing obligations to respect, protect and fulfill human rights and fundamental freedoms;

2. The role of business enterprises as specialized organs of society performing specialized functions, required to comply with all applicable laws and to respect human rights;

3. The need for rights and obligations to be matched to appropriate and effective remedies when breached. ${ }^{3}$

The UN Guiding Principles address States, urging them to oversee business behavior. This article, however, locates the responsibility back in the business enterprise-where many activities and decisions originate.

After making the case for greater development of this intersection between market actors and genocide studies, this article uses the contemporary debates over French National Railways (SNCFSociété Nationale des Chemins de Fer Français)'s role in the transport of deportees towards death camps during World War II as a case study. The purpose of this article is not to condemn or expunge the SNCF, rather to consider how the various iterations of the on-going conflict highlight many of the contemporary conundrums when we consider corporate complicity in genocide and massive human rights violations. When the Germans occupied France during WWII, they requisitioned the rolling stock of the railroad. The SNCF carried out German requests as well as those required to keep France running. The German demands, which included shipments of soldiers and armaments, also included the order to transport roughly 76,000 mostly foreign-born Jews to the German border where a German driver then took them to Auschwitz. Most deportees suffered during the thirty-six hours that they were packed in merchandise cars with no food, water, light, or sanitation. Current estimates say that only 3,000-5,000 of the original 76,000 Jews transported survived the voyage and the death camps.

\footnotetext{
${ }^{1}$ Steven Coll, interview by Amy Goodman, Democracy Now, May 4, 2012.

${ }^{2}$ The UN term "remedy" suggests that the problem can be fixed. In the cases discussed in this article, the harm is irreparable and cannot be remedied as a case of poison ivy might be. Instead, this article refers to responding to human rights violations rather than providing remedies.

${ }^{3}$ John Ruggie, Guiding Principles on Business and Human Rights: Implementing the United Nations "Protect, Respect, and Remedy" Framework (New York and Geneva: United Nations Human Rights, 2011), 1.
} 
After the war, the company went on to become a successful global rail company, bidding for contracts also in the United States where a small, but powerful group of survivors and their lawyers vowed to keep the company out of the country until it paid survivors directly for their losses. Via lawsuits and legislation, the conflict has rolled on for decades. The SNCF's head of Corporate Social Responsibility - Bernard Emsellem - and SNCF America CEO Alain Leray were both tasked with handling the SNCF's response to repeated attacks.

While the question of the company's guilt and innocence is of great interest and the focus of other works, this article considers the SNCF conflict in order to understand how post-conflict treatment of corporations can unfold and the lessons learned from this process. ${ }^{4}$ Additionally, deep consideration of the role of market actors requires moving beyond simply binaries of guilt and innocence. Tyranny and mass violence create extreme and complicated contexts in which individuals operate and make moral decisions. At the moment they are made, these decisions may not appear as moral choices or even as decisions. But they can have serious repercussions. To embrace the complexity, this article addresses how victimized individuals sought amends, how the company responded, and how the field currently addresses and/or avoids conundrums relevant to corporate accountability.

The scholarship emerging from the field of corporate social responsibility (CSR) can help genocide studies tackle difficult questions, such as: Where within a business does accountability reside? Are agents, shareholders, or executives responsible? For how long? The field of CSR can also help guide discussions around the ethos of businesses giving rise to policies and behaviors that prohibit or promote life-supporting behavior. In return, genocide studies - and the related field of transitional justice - can help expand CSR beyond labor rights and environmental issues to more fully consider forms of remedies and prevention necessary in the context of mass violence.

\section{Genocide Studies, Transitional Justice, and Market Actors}

Traditionally in genocide, peace studies, and conflict studies, discussions involving market actors falls into two categories: economic crimes (looking backward) and economic rights (looking forward). ${ }^{5}$ Economic crimes range from pillaging, ill-gotten gains, and starvation, to more general accusations of corruption and greed. The second category speaks to the ways in which industry figures into long-standing economic inequality both as a complicit actor and a means of advancing Social, Economic and Cultural (SEC) rights. ${ }^{6}$ This article focuses on economic-related crimes.

Historically, genocide studies and related disciplines have sidelined issues of economic crimes. Current discussions remain relatively sparse. ${ }^{7}$ Zinaida Miller notes that Ruti Teitel's

\footnotetext{
${ }^{4}$ For more information on the SNCF's complicity during WWII please see: Sarah Federman, Aller Simple (One-Way Ticket) Corporate Accountability for Mass Atrocity: A Study of the French National Railroads. Dissertation. George Mason University, 2015; and Ludivine Broch, Ordinary Workers, Vichy and the Holocaust: French Railwaymen and the Second World War (Cambridge, UK: Cambridge University Press, 2016).

${ }^{5}$ Zinaida Miller, "Effects of Invisibility: In Search of the 'Economic' in Transitional Justice," International Journal of Transitional Justice 2, no. 3 (2008), 266-291. See also Wendy Lambourne, "Transitional Justice and Peacebuilding after Mass Violence," International Journal of Transitional Justice 3, no. 1 (2009), 28-48.

${ }^{6} \mathrm{SEC}$ rights include the right to education, housing, and health. The International Covenant on Economic, Social and Cultural Rights (ICESCR) serves as the international legal guideline for these rights. These rights address questions of access, but not necessarily structural factors.

${ }^{7}$ Ruben Carranza, "Plunder and Pain: Should Transitional Justice Engage with Corruption and Economic Crimes?" International Journal of Transitional Justice 2, no. 3 (2008), 310-330. See also Miller, Effects of Invisibility. Louise Arbour, "Economic and Social Justice for Societies in Transition," New York University Journal of International Law and Politics, 40, 1 (2007), 4; Ismael Muvingi, "Sitting on Powder Kegs: Socioeconomic Rights in Transitional Societies," International Journal of Transitional Justice 3, no. 2 (2009), 163-182; Hugo Van der Merwe and Audrey R. Chapman, Assessing the Impact of Transitional Justice: Challenges for Empirical Research (Washington, DC: United States Institute of Peace, 2008); R.L. Nagy, "The Scope and Bounds of Transitional Justice and the Canadian Truth and Reconciliation Commission," International Journal of Transitional Justice 7, no. 1 (2012), 52-73; E.F. Drexler "Fatal Knowledge: The Social and Political Legacies of Collaboration and Betrayal in Timor-Leste," International Journal of Transitional Justice 7, no. 1 (2013), 74-94; Lauren Marie Balasco, "The Transitions of Transitional Justice: Mapping the Waves From Promise to Practice," Journal of Human Rights 12, no. 2 (2013), 198-216; Kora Andrieu, “Dealing With a 'New' Grievance: Should Anticorruption Be Part of the Transitional Justice Agenda?" Journal of Human Rights 11, no. 4 (2012), 537-557; Tricia D. Olsen, Andrew G. Reiter, and Eric Wiebelhaus-Brahm, "Taking Stock: Transitional Justice and Market Effects in Latin America," Journal
} 
respected genealogy of transitional justice, for example, only addresses economics as it relates to the widening gap between the rich and poor in the post-Cold War era. Miller says John Elster also treats economics as a separate domain. ${ }^{8}$

In post totalitarian regimes, questions of the ill-gotten gains of individuals - rather than role of corporate entities - dominate economic and business related discussions. In 2005, the UN Convention Against Corruption (UNCAC) declared asset recovery a primary goal, along with establishing corruption as a criminal offense. ${ }^{9}$ Within its charter, the International Criminal Court (ICC) has the right to obtain proceeds from ill-gotten gains and use the gains to support victim recovery programs. The new Peruvian government, for example, successfully recovered assets from Peru's former President, Alberto Fujimori and his collaborators, and then used these funds to support reparations and truth seeking programs. ${ }^{10}$ Ruben Carranza claims the field focuses primarily on asset recovery because it is the easiest corruption-related issue to address. However, focus on asset recovery can obscure the powerful role market actors continue to play.

While the post-war SNCF conflict about amends began as fight about the company's complicity in genocide, because of legal lacuna, the most recent lawsuits focus on theft (i.e. ill gotten gains). The April 2015 class action lawsuit filed against the company focuses on items, "illegally, improperly and coercively taken from the ownership or control of an individual during the deportations." 11 This article will consider the treatment of market actors in the field of genocide studies before turning to the SNCF conflict.

\section{The Marginalization of Corporate Accountability}

To encourage discussion about market actors, it is helpful to consider what contributes to a general sidelining of these issues. Corporations so powerfully structure culture socially, economically and politically, marginalizing them in conflict work seems dangerous. Proposed scholarly explanations for the marginalization of business in genocide studies include:

1. legal lacunae,

2. development and post-conflict work prefers short-term projects, and

3. power elites and structural forces mask culpability.

A number of scholars note how the structure of international law makes it difficult to discuss the culpability of economic actors in mass atrocity. ${ }^{12}$ The ICC has no teeth with which to bite down on corporate giants. The court can only prosecute a natural person not a legal person. Even if the ICC and other criminal courts could try legal persons, the prosecution would have the difficult task of proving the accused entity possessed both a mens rea (guilty mind) and an actus reus (guilty act). The question of whether the corporate consciousness resides solely within the company's agents or exists as something greater than the whole, has vexed scholars for years. ${ }^{13}$

of Human Rights 10, no. 4 (2011), 521-543.

${ }^{8}$ Miller, Effects of Invisibility, 266-291.

${ }^{9}$ United Convention Against Corruption, UN General Assembly Resolution A/RES/58/4. Implemented 14 December 2005. Examples of ill-gotten gains include Augusto José Ramón Pinochet who had multiple offshore accounts, Sani Abacha from Nigeria amassed four billion dollars in assets, the DRC's Mubuto Sese Seko collected an estimated twelve billion dollars, and Indonesia's Suharto hoarded nine billion dollars in assets. See Carranza, Plunder and Pain. The U.S. Alien Tort Statute (ATS) from 1789 was enacted in the in 2004 trial against the Marcos family in the Philippines (Hilao $v$. Estate of Ferdinand Marcos) regarding their billion-dollar estate. Most of embezzlement remains at large.

${ }^{10}$ Carranza, Plunder and Pain.

${ }^{11}$ AFP, “US families of Holocaust victims sue SNCF," The Local, April 17, 2015, accessed January 2, 2017, http://www. thelocal.fr/20150417/holocaust-victim-descendants-sue-frances-sncf-in-us.

${ }^{12}$ Arbour, Economic and Social Justice, 1. See also Kieran McEvoy, “Beyond Legalism: Towards a Thicker Understanding of Transitional Justice," Journal of Law and Society 34, no. 4 (2007), 411-440. Miller, Effects of Invisibility. Rosalind Shaw, Lars Waldorf, and Pierre Hazan, Localizing Transitional Justice: Interventions and Priorities after Mass Violence (Stanford: Stanford University Press, 2010).

${ }^{13}$ John Dewey, "The Historic Background of Corporate Legal Personality," Yale Law Journal 35 (1925), 655. Sir John William Salmond and Patrick John Fitzgerald, Salmond on Jurisprudence (London: Sweet \& Maxwell, 1966). William S. Laufer, “Corporate Bodies and Guilty Minds," Emory Law Journal 43 (1994), 647. 
During genocidal periods, enterprises may have only contributed to bodily harm indirectly. This makes ascribing accountability difficult. Enterprises may have transported soldiers, provided fuel, housed monies, or fabricated materials used in combat. What accountability would fervent Nazi, Hugo Boss' company, for example, have for proudly producing Nazi SS uniforms? In the case of Rwanda, Radio-Television Libre des Mille Collines (RTLMC) was launched by Hutu extremists to foster hate and galvanizing support for the forthcoming genocide. What is the responsibility of this station for its role? These questions remain difficult to answer and as a result the enterprises find themselves largely expunged.

\section{Concerns About Corporate Accountability}

Some scholars avoid corporate accountability because such they fear it promotes collective guilt, which leads to blame and shame cycles that impede reconciliation and healing. ${ }^{14}$ Former U.S. Secretary of State Madeline Albright, agrees. She believes moving forward requires holding individuals accountable in order to expunge the collective. ${ }^{15}$ Lars Waldorf attributes the avoidance of market actors more to the failure of communism and the general decline of the left. ${ }^{16}$ This decline led to what Louise Arbour-former UN High Commissioner for Human Rights - calls a "deep ambivalence within justice about social justice." ${ }^{17}$ Ruben Carranza believes this ambivalence created resistance within human rights discourse to unite political and civil rights issues with economic ones. Economic issues became taboo. Elie Wiesel observed this taboo. He noted that people often argued that negotiations of ill-held bank accounts distract from the more "noble" work of remembering the dead..$^{18}$

\section{Privileging Easy Success}

Short-term "transition" projects with proven models of success take precedence over messy business issues. ${ }^{19}$ Transitional justice scholar Lars Waldorf purposefully marginalizes questions of market actors arguing that inclusion could make the field so enormous as to be meaningless. ${ }^{20}$ Others express concern that issues of corruption, fraud, and business crime, may be too difficult for the field to disentangle. ${ }^{21}$

\section{Power Elite Obstruct Access}

Perhaps the most difficult challenge to accountability for market actors is that powerful elites refuse to allow their financial streams to be interrupted. Structural changes may anger elites upon whom development and peacebuilding depends. ${ }^{22}$ After the fall of regimes in Latin America and Eastern Europe, for example, prior leaders and their military supporters retained much power and could

\footnotetext{
${ }^{14}$ Martha Minow, Between Vengeance and Forgiveness: Facing History after Genocide and Mass Violence (Boston: Beacon Press, 1999). John Braithwaite, “Restorative Justice: Theories and Worries," Visiting Experts' Papers: 123rd International Senior Seminar, Resource Material Series 63 (2004).

${ }^{15}$ Madeline Albright, From Words to Action, the Responsibility to Protect, The United States Holocaust Memorial Museum, 23 July 2013.

${ }^{16}$ Lars Waldorf, "Anticipating the Past: Transitional Justice and Socio-Economic Wrongs," Social \& Legal Studies 21, no. 2 (2012), 171-186.

${ }^{17}$ Arbour, Economic and Social Justice, 1.

${ }^{18}$ Stuart Eizenstat, Imperfect Justice: Looted Assets, Slave Labor, and the Unfinished Business of World War II (New York: Public Affairs, 2009), $x$.

${ }^{19}$ Miller, Effects of Invisibility. Paige Arthur, "How 'Transitions” Reshaped Human Rights: A Conceptual History of Transitional Justice," Human Rights Quarterly 31, no. 2 (2009), 266-291.

${ }^{20}$ Waldorf, Anticipating the Past, 171-186. Paul Gready, The Era of Transitional Justice: The Aftermath of the Truth and Reconciliation Commission in South Africa and Beyond (London: Routledge, 2010).state-ownership but can participate in commercial activities normally prohibited by state entities.

${ }^{21}$ Alan Doig and Stephanie Mclvor, "Feature Review Corruption and its Control in the Developmental Context: An Analysis and Selective Review of the Literature," Third World Quarterly 20, no. 3, (1999), 657-676.

${ }^{22}$ Graham Brown, Corinne Caumartin, Arnim Langer, and Frances Stewart, "Addressing Horizontal Inequalities in PostConflict Reconstruction," in Rethinking Transitions: Equality and Social Justice in Societies Emerging from Conflict, ed. Gaby Oré Aguilar and Felipe Gomez Isa (Portland, OR: Intersentia, 2011).
} 
reignite violence. It would have been too much, Naomi Roht-Arriaza argues, to prosecute this elite for all their corruption. Trials would have destabilized the state.

Even in peacetime, corporations and their agents create and reinforce power structures that resist accountability. According to Johan Galtung, "when the structure is threatened, those who benefit from structural violence, above all those at the top, will try to preserve the status quo so well geared to protect their interests. ${ }^{\prime 23}$ France was no exception. For years, French President Mitterrand protected befriended collaborators from legal and political attack. The French Catholic Church and Georges Jean Raymond Pompidou (France's Prime Minister 1962-68) also sought to preserve the structural elite. Together they pardoned Paul Touvier, a lead French collaborator with the Nazis. Eventually, Touvier became the first convicted in France for crimes against humanity. Prior, Touvier, along with René Bousquet and Maurice Papon (who ran the Vichy police that organized and conducted the round-ups) all had great post-war careers both in government and business. ${ }^{24}$

Most corporate leaders involved in and profiting from Nazi efforts and slave labor largely walked away. ${ }^{25}$ Their companies remained intact. The 2 nd Military Tribunals conducted by the U.S. Military moved to hold a dozen corporate board members held accountable at Nuremberg for their companies' support of the Nazi war effort or various crimes against humanity. While the trials served as a birthplace for corporate liability for crimes against humanity, no corporate mogul served more than eight years in prison. Most went on to build post-war Europe in various capacities.

In spite of this light treatment, these trials served as the beginning of corporate accountability debates. Kevin Jon Heller and other distinguished Nuremberg scholars argue that accountability of legal persons (corporations) first began after the war. Heller and his colleagues pointed to the Allied Control Council, an international body operating in Germany after the war, which held corporations accountable. The work of this council led to the

dissolution of corporations and the seizure of their assets. Indeed, even before the first Nuremberg trial began, the Allied Control Council had already dissolved a number of German corporations, including most prominently the world's largest chemical corporation Interessengemeinschaft Farbenindustrie Aktiengesellschaft ("I.G. Farben"), and seized their assets. ${ }^{26}$

Heller asserts that the origins of corporate accountability actually reside in Holocaust-implicated companies. The SNCF conflict and other contemporary conflicts offer an opportunity to see how little or much the field has advanced since 1949 when the Council completed its work.

\section{The Resources to Skirt Accountability}

Today corporate structures as compared to war-torn World War II companies have even more momentum and means to support the status quo. Many corporations and elites who play large economic roles have political and financial means to prolong and appeal lawsuits, delaying or nullifying payments. Ruben Carranza notes how Pinochet, Marcos, and Suharto all used their stolen assets to stop or limit investigations. More recently, in 2012, a court in Ecuador attempted to hold Chevron accountable for environmental damage since the 1960s. However,

${ }^{23}$ Johan Galtung, “Violence, Peace, and Peace Research,” Journal of Peace Research, 6, no. 3 (1969), 179.

${ }^{24}$ Richard J Golsan, "Crimes-against-Humanity Trials in France and Their Historical and Legal Contexts: A Retrospective Look," in Atrocities on Trial: Historical Perspectives on the Politics of Prosecuting War Crimes, ed. Patricia Heberer and Jürgen Matthäus (Lincoln: University of Nebraska Press, 2008).

${ }^{25}$ See Benjamin B. Ferencz, Less Than Slaves: Jewish Forced Labor and the Quest for Compensation (Cambridge, MA: Harvard University Press, 1979).

${ }^{26}$ Kevin Jon Heller, “Nuremberg Scholars Amicus Brief in Kiobel," Opinio Juris, December 23, 2011, accessed February 17, 2017, http://opiniojuris.org/2011/12/23/nuremberg-scholars-amicus-brief-in-kiobel/.

I.G. Farben was disbanded for its role in the German war effort, not for its production of the Zyklon B gas used to kill Jews and other deportees. Note, the brief was signed by a variety of Nuremberg scholars including, Omer Bartov, Michael Bazyler, Donald Bloxham, Lawrence Douglas, Hilary Earl, Hon. Bruce Einhorn, David Fraser, Sam Garkawe, Stanley A. Goldman, Gregory S. Gordon, Michael J. Kelly, Matthew Lippman, Michael Marrus, Fionnuala D. Ni Aolain, Kim Priemel, Cristoph Safferling, and Frederick Taylor. 
the $\$ 18$ billion settlement has been called unenforceable. The company refuses to pay and the government has no means by which to demand payment. ${ }^{27}$ The SNCF used its legal counsel, clout, lobbying, and its relationship to the French government to avoid all direct liability. In 2014, the SNCF spent over $\$ 250,000$ on U.S. based lobbying efforts related to WWII-related accusations. ${ }^{28}$ In contemporary conflicts, lawyers and lobbyists can walk away with significant financial gains.

\section{French National Railways (SNCF) and the Holocaust $\mathrm{t}^{29}$}

The contemporary conflict involving the SNCF provides a rich opportunity to consider corporate accountability in the wake of atrocity. Even though the events occurred over seventy years ago, the case study provides a rich opportunity to see how corporations can skirt legal liability. As noted earlier, this article is not a polemic for or against the legal battles, but rather uses them to demonstrate larger points about corporations' ability to circumvent legal liability, even for participation in the worst crimes.

Created in 1938, the SNCF began as a conglomerate of five major private rail companies operating in France. When they came together, the former private owners retained a $49 \%$ share of the company; the state acquired $51 \%$. The company would be considered state-owned but tried under civil law. (This hybrid public-private identity would complicate questions of accountability for decades to come.) At the start of the war, the company boasted 400,000 employees. ${ }^{30}$ The 1940 Armistice signed with the Germans placed the railroad's rolling stock under Nazi command. While the SNCF maintained daily operations, the company also transported German soldiers, armaments, livestock, and other goods for a fee. The Germans rarely paid the full amounts billed by the SNCF. Germans also ordered the deportations which SNCF workers, reluctantly or not, carried them out. Almost eighty-thousand Jewish deportees found themselves crammed aboard cattle cars headed towards their death. The SNCF did not plan this annihilation, though - at least in France-the successful deportation of the Jews required the company's participation. Even if the SNCF workers could claim ignorance regarding the destination, the sight of the deportations themselves were a clear massive human rights violation.

A French military policeman who managed the convoy leaving from Gurs-the French internment camp-September 1, 1942 provided the following description:

In truth, the special train of September 1st was transporting a mixed group of men, of women; of elderly, of sick and wounded were left to their fate once the train had departed. With the exception of those traveling in the two passenger cars, the group was parked on straw, humid with urine. The women were desperate, without hope, to satisfy their natural needs out of the sight of strangers. The site of this train left a powerful and negative impression on the non-Jewish French population who saw it. ${ }^{31}$

Over seventy convoys left France for Auschwitz. Every train reached its destination and no documents yet found indicate direct resistance from the SNCF management. ${ }^{32}$ Some post-war

\footnotetext{
${ }^{27}$ Manuel A. Gomez, "The Global Chase: Seeking the Recognition and Enforcement of the Lago Agrio Judgment Outside of Ecuador," Stanford Journal of Complex Litigation 1, no. 199 (2013), 13-14.

${ }^{28}$ Open Secrets.org, Center for Responsive Politics. SNCF America Issues, 2014, accessed January 2, 2017, http://www.opensecrets.org/lobby/clientissues.php?id=D000065089\&year=2014.

${ }^{29}$ These findings are based on archival work and over 120 interviews with involved parties in France and the United States. Research also included participant observation at commemorative sites, legislative debates, the State Department Treaty signing, and pro bono work at the House of Representatives and the U.S. State Department.

${ }^{30}$ As a result of the transition away from coal, today the company employs closer to 250,000 individuals.

${ }^{31}$ Marie-Noëlle Polino, Association pour l'histoire des chemins de fer en France (AHICF), Une entreprise publique dans la guerre la SNCF 1939-1945. Paris, Assemblée Nationale : 21-22 Juin 2000 (Paris: Presse Universitaires de France (PUF), 2001), 200.

${ }^{32}$ Note: While this thesis focuses specifically on the Jewish deportations, political prisoners and others also found themselves on these trains to Auschwitz. My dissertation outlines the information available and the debates that remain over the SNCF's ability to resist and any say it had over the conditions of the transports. Federman, Aller
} 
accounts by SNCF cheminots (railway workers) indicate concern and sympathy for those crammed into these transports by French police. ${ }^{33}$ The transports could not have occurred without the SNCF and the company's ability to resist remains a question. Could more have been done? Are contemporary SNCF executives and shareholders responsible for the inability and/or refusal of its predecessors to successfully resist? What has been the response of other complicit companies?

Though created as a state-owned enterprise in 1938 and then placed under German control during the war, the SNCF liked to think of itself as operating independently. ${ }^{34}$ In many ways, the company organized its daily operations. In 1940, Nazis briefly set up a transportation division in Paris and within a month returned all control, except for the costal operations, back to the French. As a result, from 1939 to 1941, the SNCF fulfilled (and billed for) all German requests while retaining majority of control over its operations. The SNCF usually consulted the Vichy government, not the Germans, regarding its activities. During these years, the Germans rarely issued orders but when they did, the SNCF responded unenthusiastically to German involvement in its affairs. December 29, 1942, President Münzer, the Nazi responsible for French rail activity, wrote a letter to the SNCF saying, "The spirit of collaboration within the SNCF leaves something to be desired." ${ }^{35}$ The transportation division of over which Münzer presided, issued a number of statements expressing its dismay over the SNCF's lack of willingness to collaborate. The lack of enthusiasm at the executive level became most visible after the German defeat at Stalingrad in February of $1943 .^{36}$ The railroad sabotage increased throughout the war, climaxing on D-day and continuing until the liberation of France.

The acts of resistance were vital and required great bravery. There were heroes and many engaged in heroic acts silently. Throughout the war, however, as an organization the disgruntled SNCF cooperated more than it resisted, fulfilling most German orders on time and with relatively little supervision. The Nazis had relatively few Germans to spare to manage the French occupation. A relatively small group of 60,000 German soldiers arrived in France to oversee forty million people. Only 6,000 Nazis monitored 400,000-500,000 SNCF workers. Supervising so many individuals with so few Germans, required complicity on many levels. Successful occupation relied on a variety of insiders who become necessary accomplices. ${ }^{37}$ Some provided these services fearing the consequences of non-adherence and others, less gloriously, used the occupation to advance their careers or status. Germans demanded complicity with greater intensity as the war went on. The question of whether the SNCF collaborated with or resisted the occupation is a large and complicated subject handled by my dissertation and Ludivine Broch's work. ${ }^{38}$ For the scope of this article, the story has been compressed. Ultimately, the SNCF did not like being under the German thumb. There were acts of the resistance among some of the railway workers, but the executives seemed to largely collaborate. Most acts of resistance sought to disrupt the occupying forces rather than to save the deportees. The few attempts on the behalf of those crammed aboard the cattle cars,

Simple (One-Way Ticket).

${ }^{33}$ Paul Durand, La SNCF pendant la guerre (Paris, France: Presses Universitaires de France, 1968).

${ }^{34}$ Vichy historians differ over the amount of independence the clause afforded. Historian Georges Ribeill interpreted the Armistice as forcing the SNCF to operate exclusively under German authority. Historian and economist Michel Margairaz agreed, arguing that the SNCF operated under the thumb of both the complicit French government and the German occupier. Georges Ribeill, “Dossier SNCF et Déportations," Historail 4 (2008); 46. Annette Wieviorka, however, interpreted the clause differently, arguing the SNCF retained ownership of its materials (trains, wagons, etc.) while the German head of transport managed all of the operations of the trains (schedules, etc.) Wieviorka claims this perceived additional independence afforded the railway company created a bit of 'jealousy' within the Vichy regime wished greater independence from the Germans.

${ }^{35}$ Monsieur de Directeur Général with M. le Président Münzer à la HVD, le 29-12-42. 3 January 1943, Box 72 AJ 474. National Archives of Paris, France.

${ }^{36}$ Christian Bachelier and Centre National de la recherche scientifique (CNRS), La SNCF Sous L'Occupation Allemand 19401944. (France: AHICF, 1996). Note, the battle of Stalingrad, August 23, 1942 through February 2, 1943, is seen as the turning point of the war. The Germans never regained their positions after this defeat to the Soviets.

${ }^{37}$ Michael R. Marrus and Robert O. Paxton, Vichy France and the Jews (New York: Basic Books, 1981), xvi.

${ }^{38}$ Federman, Aller Simple (One-Way Ticket). Ludivine Broch, Ordinary Workers, Vichy and the Holocaust: French Railwaymen and the Second World War (Cambridge, UK: Cambridge University Press, 2016). 
however, were well remembered and much appreciated ${ }^{39}$ The question of whether the SNCF knew the destination of the cattle cars remains debated. The executives likely knew, though the train drivers who descended at the German border could likely not imagine the death camps at the end of the line. Deportees themselves could hardly believe the rumors of Jews being incinerated upon arrival. While knowledge of the destination had been limited, clearly the horrendous conditions were visible to all near the wagons. The screams and lack of food, air, water, sanitation and space were themselves torture. Even bystanders, like Édith Thomas, witnessed these conditions. She said,

I saw a train pass by; at the head of the train, a wagon containing the French military police and the German soldiers. Then, came the cattle cars, packed. The skinny arms of children clinging to the bars. A hand outside flapping like a leaf in a storm. When the train stopped voices cried, "Momma!" 40

The German occupier ordered the deportations. They mostly determined the conditions and the SNCF workers carried them out. ${ }^{41}$ The company, a complex, enterprise of almost half a million employees embodied the complexities of France and the complexities of occupation. On a daily basis, there were moments of collaboration, resistance, bravery, cowardice, and everything in between. This further complicates the question of accountability. Who is responsible for the SNCF's role in the deportations? Contemporary executives? The French taxpayer? And for how long? SNCF executives, engineers, conductors, and others enabled those trains to depart. As of 2016, all the involved individuals have passed away - only questions of accountability remain. The answers are not clear, even to the survivors. Of the over 80 Holocaust survivors interviewed for this research, the majority were unsure about whether holding the contemporary company accountable made any sense. ${ }^{42}$ While unsure about what to do with the contemporary company, most agreed that France's moves towards accountability were frustratingly slow.

\section{Post-War France}

Immediately after the war, Holocaust victims remained unrecognized as a distinct group, having suffered persecution as well as war wounds. Of the eighty survivors interviewed for this research, only a couple boasted more than sixteen-years of age at the time of the war. They recalled a postwar home life more brutal for many than the war itself. Many had lost families and identities and struggled to find food, money, education, and any feeling of safety. After surviving Auschwitz, Daniel-age fourteen-recalls approaching the bank to withdrawal the little money left by his parents both murdered in the camp. The bank sent him away explaining the account had been closed for disuse. "I understood they had their policies," he explained, "but it was deeply painful to be sent away like that."43

The bank held and made use of the assets until the 1990s when the French-initiated Mattéoli Commission and a U.S. class action lawsuit would return those assets. Immediately after the war, many found not just their assets frozen, but their voices too. They were unable to speak freely. At home, they could ask nothing of their parents and express little of their own suffering. They said people wanted to move on and with scarce food and jobs; few had time or energy to pursue justice or lick wounds. Survival came first, concerns about justice came later.

\footnotetext{
${ }^{39}$ These attempts are addressed in Federman, Aller Simple (One-Way Ticket), Paul Durand, La SNCF pendant la guerre (Paris: Presses Universitaires de France, 1968). Broch, Ordinary Workers.

${ }^{40}$ Robert Paxton, Stanley Hoffman, and Claude Bertrand, Vichy France: Old Guard and New Order, 1940-44 (New York: Knopf, 1972), 180.

${ }^{41}$ Surviving invoices suggest the SNCF received payment for transporting deportees to various internment camps within France. No remaining invoices prove the SNCF received payment to transport deportees to the German border crammed in cattle cars.

${ }^{42}$ These interviews were conducted in France and the United States with individuals who fled the persecution of the Jews in France during the war.

${ }^{43}$ Interview, April 30, 2016.
} 
In France, however, little by little people started to speak up by recording their memories, requesting archival material, or making claims for lost possessions. Some worked to reveal collaborators or in other ways make sure their experience was included in the collective memory. Time, global events, as well as historical works also helped upend the silence. After forty years, some public archives opened, enabling people to access information about accounts and government activities. Raul Hilburg's, The Destruction of European Jews (1961) based on German documents detailed in six volumes the bureaucracy of annihilation. The fall of the Berlin Wall, leading to the end of the Cold War, meant the United States no longer needed Germany and Switzerland to help protect it from the U.S.S.R. Tens of thousands of survivors, many of who lived in the United States, could launch transnational holocaust litigation for stolen assets. French documentarian, Claude Lanzmann, prompted conversation through his nine-hour documentary, Shoah, in which he interviewed the individuals who perpetrated the crimes. France was also shaken by archival work of Robert Paxton and Michael Marrus's archival work, which proved the anti-Semitic policies initiated by France without German interference. With increased voices came additional political trials, compensation programs, and the unleashing of transnational holocaust litigation. During this time, the SNCF found itself in court. (See Table A for related lawsuits)

\section{SNCF Accountability Debate}

While the events of the Holocaust date back seventy years, genocide scholars and justice seekers continue to live in the questions the atrocity provoked. Some of those touched by the persecution demand financial compensation. A powerful group of lawyers, legislators, and survivors linking Holocaust injustice to United States regional and high-speed train bids continue to make headlines with their calls for justice. The group fighting the company wants the SNCF to be more transparent regarding its wartime role and to compensate victims before advancing business interests in the United States where it and its subsidiary Keolis bid for contracts.

Since the war, the SNCF's power and reach had increased nationally and internationally. The shift away from coal reduced the need for employees by $50 \%$ (now down to 250,000). The SNCF had become and continues to be a world class railway and transport company. The SNCF is a strong competitor against Japanese, German, and other leaders in rail travel. The SNCF's earnings reflect its global strength. In 2013, the company reported its worldwide revenue as 32.2 billion Euros (roughly $\$ 44$ billion dollars). ${ }^{44}$ The company remains a public-private hybrid as it has since its inception. According to Bernard Emsellem, SNCF's head of Corporate Social Responsibility, today France classifies the SNCF as an Etablissement Public Industriel et Commercial (EPIC) - a public establishment of industrial and commercial nature. This means the company is still state-owned but can participate in commercial activities normally prohibited by state entities..$^{45}$ Holding this global, partially state-owned enterprise legally accountable for Holocaust crimes has proved impossible.

The company's social notoriety also makes it a difficult target. Julius, who lost his parents and siblings in the deportations points out one of the primary reasons, "You are well aware, I am sure, that the subject is very 'delicate.' La SNCF, C'est la France!" The SNCF is France! ${ }^{46}$ The company logo closely resembles the French flag and is almost as ubiquitous as the McDonald's sign in the United States. The trains serve as the veins through which nearly every person and product eventually flows. Do these trains bear the responsibility?

The father of Holocaust research Raul Hilberg was not so quick to dismiss the accountability of the individual railway man. He argued in 1976 that these railway workers were, "not mindless robots. As intelligent men they were capable of understanding the tenor of their time." ${ }^{47}$ Among scholars, his view is not the most common one today. Many site the complexity of the times and the complexity of collective accountability. Ralph Steinhardt argues, for example, that corporations cannot be held accountable for the government's poor decisions,

\footnotetext{
${ }^{7644}$ SNCF, Profile and Key Figures (Booklet), 2013.

${ }^{45}$ Email correspondence. March 9, 2015.

${ }^{46}$ Phone Interview July 7, 2014. Note: names of survivors have been changed.

${ }^{47}$ Raul Hilberg, German Railroads/Jewish Souls, Society 14, no. 1 (1976), 7.
} 
No one can be held responsible for acts beyond his or her control... corporation cannot be held liable for a host government's systemic violations of civil, political, and cultural rights, unless the corporation contributes to the violation... ${ }^{48}$

Steinhardt, therefore, would likely expunge the SNCF past and present arguing that the SNCF found itself caught up in the government's political commitments. In addition to governmental control, the SNCF had its own set of norms and structures that might have made widespread resistance difficult. Vichy historian, Ludivine Broch observed the powerful forces of "hierarchy, obedience, and personal advancement" that existed within the SNCF. ${ }^{49}$ Her scholarship suggests that cheminot fidelity to the trains and each other superseded any notions of human rights or any larger moral imperative.

Questions of group accountability within the moral framework of an agency remain a muchdebated subject. Vichy historian Michael Marrus challenges the accountability Hilberg promoted, saying that it creates a slippery slope, "After the trains, people went on buses," Marrus says,

So are you going to sue the bus company? What about the postal service for notices sent to Jews during the War?...Anyone who showed any signs of independent activity, anyone who would not discharge the requirements of the Reich, was purged. ${ }^{50}$

Marrus claims the consequence of any deviance was death; the price proved too high to expect anyone to rebel. Others argue that the SNCF's affiliation with the Nazis was too loose to ascribe accountability. In 2011, French radio journalist Hervé Gattegno made this bold comparison,

I don't think we can say that SNCF as a company was any more associated with this atrocity than the American airline companies were with the 9/11 attack. And I don't see why SNCF agents today should have to bare the burden of this terrible past. ${ }^{51}$

Public pressure and lobbying have continued for over ten years, providing on-going opportunities to discuss these issues. The efforts of the plaintiffs catalyzed a large French settlement-discussed later in the article-and helped the SNCF become a large supporter of Holocaust commemoration in France. The courts, however, remain inaccessible to those trying to ascertain legal liability.

\section{French Lawsuits}

This article addresses the challenges of holding market actors legally accountable for participation in atrocity, beginning with the SNCF. For years, in France no one was allowed to even sue the State for Vichy policies. In 1952, the Conseil d'Etat, France's highest administrative court, considered the Epoux Giraud case. The court rejected demands for compensation for victims suffering under the anti-Semitic legislation and deportations policies on the basis that the policies never existed. The court based this ruling on the August 9, 1944 ordinance which declared the Vichy Regime a de facto government and thereby considered all its policies null and void. ${ }^{52}$ The state declared this policy while deporting individuals to Auschwitz. Convoy 78, left Lyon two days after the declaration on August 11, 1944, crammed with 650 people (438 men, 12 children, and 200 women). Only in

\footnotetext{
${ }^{48}$ Ralph G. Steinhardt, "Corporate Responsibility and the International Law of Human Rights: The New Lex Mercatori," in Non-State Actors and Human Rights, ed. Philip Alston (Oxford and New York: Oxford University Press, 2005$), 217$.

${ }^{49}$ Ludivine Broch, "Professionalism in the Final Solution: French Railway Workers and the Jewish Deportations, 1942-4," Contemporary European History 23, no. 3 (2014), 359-801.

${ }^{50}$ Amar Toor, “The Holocaust's Legacy Threatens One Company's US Rail Projects," The Verge, March 7, 2014, accessed February 17, 2017, http://www.theverge.com/2014/3/7/5480714/the-holocausts-legacy-threatens-sncf-france-us-railprojects.

${ }^{51}$ SNCF, “History and Memory: SNCF \& World War II" (Paris: SNCF, 2012).

52 “16 Février 2009 - Hoffman-Glemane," Le Conseil d’Etat et La Jurisdiction Administrative, September 28, 2015, accessed February 17, 2017, http://www.conseil-etat.fr/Decisions-Avis-Publications/Decisions/Les-decisions-les-plusimportantes-du-Conseil-d-Etat/16-fevrier-2009-Hoffman-Glemane.
} 
2002, did the Conseil d'Etat open the possibility of state responsibility. Despite this eventual transformation, no one ever succeeded against the French railway company.

The French cases and the rulings demonstrate some of the difficulties in holding market actors accountable even in countries with established court systems. The high courts had closed its doors to victims for roughly sixty years. When the gates opened, they did so only partially. Claimants had much work ahead of them. Class action lawsuits allow large numbers of people to sue without baring legal fees individually. Class action lawyers often work on contingency fees, meaning they receive payment only if they win the case. Without this system, survivors wanting to sue in France would have to pay their own legal fees without guarantee of regaining lost assets. This also means the court must hear each individual case. For tens of thousands of victims, this could occupy the court for decades. Furthermore, any winnings would only belong to the individual claimant and would not help survivors with similar losses.

In spite of these barriers, several individuals in France, with the means to do so, battled the SNCF for personal and financial reasons. The first lawsuit, Kurt Werner Schaechter $v$ SNCF was issued by a survivor who found invoices in the Toulouse archives demonstrating the SNCF received payment for transports within France. In Jean-Jacques Fraenkel $v$ SNCF the Tribunal de Grande Instance Paris rejects the case arguing insufficient evidence.

The most infamous French case, that of the Lipietz family, never led to financial compensation, but the legal reasoning used provides insight into how corporate accountability cases may be considered. On November 14, 2001, Alain and Georges Lipietz (son and father, respectively) filed against the French state for their losses related to the deportations. Their lawyer, Rémi Rouquette, advised the plaintiffs to add the SNCF to their claim. Alain Lipietz claims that his father, for whom he launched the suit, had no grudge against the SNCF, but added the company because Rouquette argued the SNCF was a distinct juridical entity, separate from the State and therefore suable..$^{53}$ They filed the case in the Administrative Court in Toulouse, citing injuries suffered by Alain's mother, father, and step-father by their arrest by the Gestapo on May 8, 1944, the SNCF trip May 10 and 11 from Toulouse to Paris-Austerlitz, and their internment at Drancy from May 11 through August 17, 1944.

Arno Klarsfeld representing the SNCF, also son of renowned French Nazi hunter Serge Klarsfeld, emphasized that the Gestapo organized transport to the Drancy internment camp (not the SNCF) and that Georges Lipietz never took the trip from France to Auschwitz. ${ }^{54}$ Arno Klarsfeld's claim suggests that the SNCF had no control over the management of the voyage. Furthermore, if Georges only travelled to Drancy, he did not endure the same transport conditions as the deportees travelling over thirty-six hours to Poland to a death camp. While George was not a willing passenger, his experience was not the grave crime against humanity suffered by over 75,000 . Without class action, the SNCF only had to prove that the Lipietz family did not experience immense tragedy. The tragedy of others is irrelevant in the judge's decision.

Post-war lawsuits faced on-going critiques. One critique is that post-war trials can be so lengthy they limit their impact. ${ }^{55}$ Cases can outlive their litigants. The Administrative Court of Toulouse read its decision to a large room of jurists, students, and journalists among others on June 6, 2006, five years after the case was filed and three years after the death of Georges Lipietz. Prosecuting lawyer, Rémi Rouquette made the following statement,

The Lipietz family did not want to go to Drancy...they did not buy a ticket to Paris and were not, in effect, customers of the SNCF. So the railway had no business having them on the train...It never did anything, or tried to do anything, to slow down the rhythm of the convoys, even after the Allied landings. ${ }^{56}$

\footnotetext{
${ }^{53}$ Alain Lipietz, La SNCF et la Shoah: le procès G. Lipietz contre État et SNCF: Essai. (Paris: Les Petits Matins, 2011).

${ }^{54}$ Arno Klarsfeld, “La SNCF et les trains de la mort," Le Monde, June 3, 2006.

${ }^{55}$ Naomi Roht-Arriaza and Javier Mariezcurrena, Transitional Justice in the Twenty-first Century: Beyond Truth Versus Justice (Cambridge, UK and New York: Cambridge University Press, 2006).

${ }^{56}$ Lipietz, La SNCF et la Shoah.
} 
In response, the SNCF's attorney reiterated the argument that the company had no autonomy during the war. He then argued a legal technicality - at the time of these events the company operated under private law. Therefore, any cases against the SNCF for these offenses would need to take place in a civil or criminal court, not an administrative one. This highlights a legal lacuna that makes it hard to convict the company-while a public company, it operates under private law. Private law largely handles individuals, rather than collective entities; in other words, an individual criminal. In this case, the court was faced with a company who no longer employed anyone who perpetrated the crimes. They were all dead.

Table A: Lawsuits Against the SNCF

\begin{tabular}{|c|c|c|c|}
\hline Year & Name of Lawsuit & Location & Outcome \\
\hline 1991 & Kurt Werner Schaechter v SNCF & France & $\begin{array}{l}\text { The court drops the case stating a } 10 \text {-year } \\
\text { statute of limitations. }\end{array}$ \\
\hline 1998 & Jean-Jacques Fraenkel v SNCF & France & $\begin{array}{l}\text { Tribunal de Grande Instance Paris rejects the } \\
\text { case arguing insufficient evidence. }\end{array}$ \\
\hline 2000 & Abrams et al. v SNCF 55 & USA & $\begin{array}{l}\text { Class action lawsuit launched. Led by Harriet } \\
\text { Tamen. District Court for the Eastern District of } \\
\text { NY dismisses the complaint saying the SNCF } \\
\text { has immunity because of the FSIA. }{ }^{56} \text { Court } \\
\text { of Appeals reinstated the case only to have } \\
\text { it dismissed by the Appeals Court after the } \\
\text { Supreme Court ruled on an unrelated case } \\
\text { that the FSIA was retroactive. Litigants appeal, } \\
\text { without success, to the U.S. Supreme Court in } \\
2005 \text {. }\end{array}$ \\
\hline 2001 & $\begin{array}{l}\text { Lipietz et al. v Prefet de la Haute- } \\
\text { Garonne and SNCF }\end{array}$ & France & $\begin{array}{l}\text { The court dismisses the case. Litigants appeal } \\
\text { and in 2006, the Administrative Court of } \\
\text { Toulouse rules against the SNCF and the } \\
\text { French government. SNCF appeals and wins } \\
\text { in } 2007 .\end{array}$ \\
\hline 2006 & Freund et al. v SNCF & USA & $\begin{array}{l}\text { Litigants (led by Tamen) seek restitution for } \\
\text { property stolen by SNCF workers and ask } \\
\text { the District Court for the Southern District } \\
\text { of NY for an exception to the FSIA. They are } \\
\text { denied. February 2011, the lawyers petition } \\
\text { the Supreme Court who denies the claim in } \\
\text { October of that same year. }\end{array}$ \\
\hline $\begin{array}{l}2008- \\
2009\end{array}$ & $\begin{array}{l}\text { Hoffmann-Glemane vs. French State } \\
\text { and the SNCF }\end{array}$ & France & $\begin{array}{l}\text { Conseild'Etat rules France owes nothing more } \\
\text { for the Holocaust. }\end{array}$ \\
\hline 2009 & Freund et al. v SNCF cont. & USA & $\begin{array}{l}\text { Southern District Federal Court NY dismisses } \\
\text { claims against France, SNCF and CDC. }\end{array}$ \\
\hline 2011 & Freund et al. v SNCF cont. & USA & $\begin{array}{l}\text { Freund et al v SNCF: Supreme Court } \\
\text { application was granted March 23rd2011 but } \\
\text { the Supreme Court never hears the case. }\end{array}$ \\
\hline 2015 & $\begin{array}{l}\text { Karen Scalin, Josiane Piquard and } \\
\text { Roland Cherrierv SNCF }\end{array}$ & USA & $\begin{array}{l}\text { Class action lawsuit, claimants seek damages } \\
\text { for international law violation, conversion, and } \\
\text { unjust enrichment. } \\
\text { Lawyers: Steven Blonder and team. } \\
\text { This focus on theft attempts to circumvent the } \\
\text { FSIA that blocked the other class action suits. }\end{array}$ \\
\hline
\end{tabular}


A Partial Win

Christophe Truilhé, the French government's commissariat, responded with the court's ruling. ${ }^{57}$ While France has no statute of limitations on crimes against humanity, this only applies to charges in criminal courts, not administrative courts like this one. The court ruled that the SNCF went beyond the demands of both the Vichy government and the Nazis. The SNCF's autonomy to pursue its financial interests during the war prevented it from being able to argue that the company could not choose the transport conditions. As a result, the State and the SNCF found themselves condemned by the Tribunal of Toulouse for their role in the deportations. The SNCF appealed while the French State paid the beneficiaries $€ 62,000$. This was a symbolic win for many and a financial gain for just a few. As mentioned earlier, without class action lawsuits, only those who launch and pay for the lawsuit receive any winnings. The decision did not create a compensation program for others.

\section{SNCF Wins and French Courts Close}

In March 2007, the Administrative Court of Bordeaux granted the SNCF the appeal, claiming the SNCF operated according to private law at the time and could not be viewed as executing a public service. Now, the Lipietz family appealed, this time before the Conseil d'Etat (the Supreme Court for administrative cases). The Conseil d'Etat found the SNCF not liable, arguing the company did not have the initiative to deport people. They claimed, however, if the SNCF had to conduct these transports, they surely did not for a minute reflect upon the consequences. In other words, the SNCF was neither a lead resistant nor lead perpetrator. This case, while not resulting in financial compensation, was a major blow to the prevailing narrative that the SNCF played a solely heroic role in the war..$^{58}$ This symbolic success unleashed a chorus of demand. Victims felt encouraged by the Lipietz near win they and their descendants filed an estimated 1800 complaints against the SNCF. ${ }^{59}$

By 2009, however, the French courts closed to all Holocaust-related cases, corporate and otherwise. The court ruled on Hoffmann-Glemane v France and SNCF that while the crimes themselves were incommensurable, pragmatically speaking, there would have to be a financial cap. No more individual cases would be heard. Michael Marrus calls the February 16, 2009 decision the decisive ending to French Holocaust litigation. ${ }^{60}$

Most Vichy historians found this ending acceptable; they believed the SNCF had done what it needed to do. French historian Henry Rousso and Arthur Goldhammer 's seminal The Vichy Syndrome (first released in 1987) addresses how the French handled Nazi occupation. In his book he coins the famous phrase, "The past that does not pass...." Today, over twenty years later, Russo believes some kind of transition has occurred. He now says, "The past is past. It's not forgotten, but it has finally found its place." ${ }^{61}$ His colleagues seem to agree. According to The New York Times,

some French historians and Holocaust experts have called the legal pressure and campaign against the SNCF in the United States uninformed and unfair. They contend that the SNCF has taken on more than its fair share of guilt, given the Nazi occupation of France and the Germans' use of French national institutions as their own. ${ }^{62}$

\footnotetext{
${ }^{57} \mathrm{~A}$ commissariat is an independent magistrate, specializing in administrative law. A commissariat is not a judge, but confers with the judge throughout the case. Their comments are influential and often reflect that of the judge at the time they are read.

${ }^{58}$ René Clément, La bataille du rail, directed by René Clément (1946; Paris: Coopérative Générale du Cinéma Français), Film. This film proliferated the heroic narrative of the SNCF. As did Paul Durand's government supported, La SNCF Pendant la Guerre.

${ }^{59}$ Michael R. Marrus and Robert O. Paxton, Vichy France and the Jews (New York: Basic Books, 1981).

${ }^{60}$ The court ruled specifically on claims sought by Madeline Hoffman-Glemane from the French State and the SNCF totaling $€ 280,000$, for the deportation and murder of her father and for her own suffering. The administrative court in Paris passed the question to the Conseil d'Etat. The state dismissed the claims against the SNCF referring to the decision issued on the Lipietz case.

${ }^{61}$ Johannes Wetzel, “'The Past Doesn't Pass' - A German Look at France's Nazi Collaboration,” World Crunch, October 15, 2012.

${ }^{62}$ Maia de la Baume, “French Railway Formally Apologizes to Holocaust Victims,” The New York Times, January 25, 2011.
} 
Michael Marrus, professor emeritus of Holocaust studies at the University of Toronto and leading expert on Vichy France, thinks the SNCF has paid its dues. Marrus finds today's efforts against France misguided. After doing archival work for the SNCF, Marrus said he is "a bit exasperated" by efforts to ban the railway from U.S. government contracts and thinks "these matters should be put to bed." He goes on to say,

I don't diminish the tragedy or the pain and suffering, but I think at the end of the day, there will never be justice in the sense that most of the perpetrators have died by now and most of the people who suffered directly have died by now, I just don't see any merit in continuing this, especially when [there has been] open acknowledgment and contrition. ${ }^{63}$

Noted French historian Annette Weiviorka agrees with Marrus that the SNCF ought to be absolved,

The SNCF has largely taken responsibility for its role in the Holocaust. Since the 1990s, the company opened its archives. In all of the train stations, it had an exposition on the deportation. Saying that the company did nothing for commemoration, like certain members of this case are saying, is unlikely. This approach is scandalous. ${ }^{64}$

French historian Georges Ribeill also discredits this conflict against the SNCF. In 2008, Ribeill wrote a fifty-six-page article on the SNCF's role in the deportations for the publication Historail. In the article, he considers the invoices produced by Kurt Schaechter in 1992 and the Lipietz family lawsuit "harassment" of the company. After completing his extensive search in the SNCF archives, Ribeill believed that French lawyers were fighting the company with judicial arguments based on little historical founding. ${ }^{65}$ The French Jewish leadership shares the sentiment of the courts and Vichy historians that France has appropriately addressed the Holocaust.

The SNCF's successful appeal and the overall closure of the French courts to Holocaust-related litigation thwarted all French legal efforts to hold the company accountable. Litigants turned to the United States where class action lawsuits flourished. One reached out to New York-based lawyer Harriet Tamen known for her work in the mid-1990s challenging the French banks for freezing victim bank accounts.

\section{U.S. Legal Battle}

In 2000, Tamen launched the class action lawsuit SNCF v Abrams et. al in the District Court for the Eastern District of NY. The court dismisses the complaint by pointing to the SNCF's immunity due to the Foreign Sovereign Immunities Act. ${ }^{66}$ The Court of Appeals reinstated the case only to have it dismissed by the Supreme Court in 2005.

The SNCF lawsuits demonstrate the kinds of legal lacuna that allow market actors to skirt around the legal system. The SNCF escaped liability because of its hybrid public-private identity. In the United States, the company positioned itself as part of the French government. In France, the company used its private identity which placed it under private law. In addition to legal loopholes, market actors have greater funds to throw at cases. Tamen took on the case pro bono.

\section{When Courts Fail: Lobbying and Legislation}

When courts fail in the United States, lobbying and legislation can be used to mount pressure. Plaintiffs against the company succeeded at this. The SNCF and its subsidiary Keolis bid for a variety of commuter, regional, and high-speed rail contracts. Many of these states have sizable

\footnotetext{
${ }^{63}$ Katherine Shaver, “Maryland Lawmaker Says He Won't Jeopardize Purple Line Funding with Holocaust Bill,” The Washington Post, March 11, 2014. Note, Aaron Greenfield, lobbyist working against the SNCF in Maryland, discredits Marrus arguing that he is on the SNCF payroll and attends many SNCF-sponsored events. Other world-renowned Vichy experts and Holocaust activists have spoken in defense of the SNCF and have been discredited for doing so.

${ }^{64}$ Annette Wieviorka, “La SNCF, la Shoah et le Juge," L'Histoire 316 (January 2007).

${ }^{65}$ Georges Ribeill, “Dossier SNCF et Déportations,” Historail 4 (January 2008).

${ }^{66}$ FSIA (the Foreign Sovereign Immunities Act of 1976) prevents lawsuits against sovereign nations.
} 
Jewish populations. This helped Tamen and her supporters succeeded in their lobbying efforts. Five states-Virginia, Maryland, New York, California, Florida-drafted legislation to create barriers for the SNCF. The legislation brought the debate national and international attention. As of January 2016, only Maryland has passed a bill. Then-Governor Martin O'Malley signed Maryland House Bill 520, which required the SNCF to digitize its archives before bidding for the MARC (Maryland Area Regional Commuter) contract. The SNCF, the favored company, complied, but ultimately lost the bid-allegedly because the competitor offered a lower bid.

The issue resurfaced in Maryland when the SNCF bid for the Purple Line contract. Joan Carter Conway (D-MD) proposed Maryland House Bill 1326 requiring the SNCF to pay restitution before bidding for the contract the federal government interceded. The U.S. State Department considers the SNCF an extension of the French state. Therefore, any complaints must be handled diplomatically. To make themselves heard, the federal government threatened to withdraw $\$ 900$ million from the project if Maryland passed the legislation. The bill died.

These state-level scuffles led to bad press and cost the SNCF considerable time and money. The U.S. public is very sympathetic to Holocaust survivors, generally even more so than French public. These remaining survivors, all children during the war, are now quite elderly and frail. This makes the U.S. public even more sympathetic. A foreign, faceless multi-national train company becomes all too easy to hate. Being a train company in particular makes the SNCF's position doubly challenging. Trains remain arguably the symbol of the Holocaust. Holocaust scholar Raul Hilberg argues that while many organizations (S.S., industrial enterprises, banks, etc.) contributed the destruction of Jews in Europe, the railroads were "indispensable at its core." ${ }^{67}$ He cites Auschwitz's forty-two parallel tracks as an example. While the 50,000 death and work camps differed in their conditions and survival rates, almost all arrived by rail. It remains the one shared experience. While Nazis succeeded in killing hundreds of thousands with bullets, the annihilation of over six million Jews could not have occurred without the railroads transporting them to death camps. Firstly, without railroads, so many Jews and other deportees could not have been taken to the camps. Trucks crammed with victims would not have been able to bring so many people such great distances. Mass atrocity requires massive efficiency-trains provided this.

\section{The Conflict Climax}

The pressure exerted by state legislation and national visibility pushed this conflict towards what seems to be the climax, if not the end. On February 6, 2014, the U.S. State Department officially began negotiating with the French government over the issue of the deportees transported on French trains. ${ }^{68}$ After months of negotiation, the two countries signed a $\$ 60$ million settlement at the U.S. State Department in December 2014 to compensate an estimated 2,000 victims and descendants around the world not covered by other French programs. ${ }^{69}$ Negotiations had been slowed by debates over how to determine nationality (many lost French nationality due to antiSemitic legislation), retroactivity, and wording created significant challenges. While the resulting agreement was not about the SNCF, the treaty required the SNCF to donate an additional \$5 million for Holocaust related research, commemoration, and programming. As of January 2015, the U.S. State Department is working ardently to distribute funds to survivors before they pass away. Monies issued today are not trivial in sum $-\$ 100,000$ - awarded to deportees not covered by other programs. As many said in interviews, they most needed the money right after the war when they had no parents, homes, or money. For those living today in impoverished conditions,

\footnotetext{
${ }^{67}$ Hilberg, "German Railroads/Jewish Souls," 70.

${ }^{68}$ U.S. State Department office of Holocaust Issues confirms this date.

${ }^{69}$ There have been French restitution programs for years. This agreement covers survivors living in countries that did not sign agreements with France to cover resident survivors. Only the United Kingdom, Poland, the Czech Republic and Belgium signed such agreements. Why the United States did not sign an agreement remains unclear. Even former Ambassador Douglas Davidson who managed the office of Holocaust Issues at the U.S. State Department could not recall why the United States never wrote such an agreement. For a detailed description of French restitution programs, see Federman, Aller Simple, (One-Way Ticket), 275.
} 
however, this money would greatly impact their comfort in their remaining years. For others it will be largely symbolic and mostly passed on to their children.

The French and U.S. governments, along with the SNCF said they hoped the December 8, 2014 settlement would stop the lawsuits and legislation. Within four months, however, on April 16, 2015-Holocaust Remembrance Day-descendants of deportees filed a class action lawsuit in Chicago attempting to hold the company accountable for theft. The conflict continues, though with far less force than before.

\section{SNCF Amends Making}

By the close of 2014, the SNCF had made roughly $\$ 10$ million in contributions towards commemoration, research, and education..$^{70}$ To demonstrate a commitment to transparency, the company opened its archives and commissioned independent research on its history. The company has also issued several formal apologies. As a result of these efforts, the French Jewish leadership now considers the SNCF a partner in Holocaust commemoration and memory. National Jewish groups in the United States - the Anti-Defamation League and the American Jewish Congress also consider the SNCF as having paid its dues. Some smaller Jewish organizations throughout the United States, a small group of survivors, their lawyers and legislators claim that without direct restitution such efforts remain insufficient. With the courts closed, they used state power to exert pressure on the company.

\section{The SNCF Conflict: Lessons Learned}

For scholars, the SNCF conflict illuminates many of the issues common across market actors. The conflict raises the question of who is accountable and for how long. The conflict also demonstrates the kind of legal lacunae making legal liability difficult to establish, even if culpability is clear. The economic power of corporations to handle the legal attacks also creates an unfair fight, especially in France where litigants had to pay their own legal fees. (Europe has begun to allow class action lawsuits, which may make corporate accountability cases largely more likely and more effective.) Without legal means to fight the company, victims used social pressure to advocate for transparency, compensation, and an apology.

For executives struggling with violations of their predecessors, the SNCF conflict also provides some learning opportunities. In Moral Repair, Walker claims accountable entities must accept a certain amount this hostility and indignation, but stop short of letting themselves become a scapegoat. ${ }^{71}$ Corporations more often could serve as an important vehicle through which injured parties can work out their justified rage. Keeping corporations out of the discussion might remove important contexts through which justice can be deliberated and agreed upon. Corporations may struggle, however, to prevent themselves from becoming a scapegoat or caught in double-binds. When the SNCF apologized, for example, some rejected the apology, believing it to be motivated by business interests. If the company did not apologize, however, its management would be considered cold and heartless. This double-bind is known as "damned if you do damned if you don't." ${ }^{\prime 2}$ Other formerly complicit actors will also face this conundrum. Still, knowing this may occur can help them think through how they might address victims' concerns about sincerity.

The SNCF's public-private identity also makes this a useful case. In many post-conflict contexts, the largest industries are tied into governments (legally or through corruption). Even if not literally connected, many governments want and need large corporate entities to generate wealth and provide jobs. Governments can be protective of national industries. The United National Guiding Principles offers guidance on how governments can respond to market actors complicit in human rights violations. The SNCF conflict fought the conflict largely on its own for several decades until the State stepped in and led negotiations. Those fighting the company wanted the SNCF to pay,

\footnotetext{
${ }^{70}$ SNCF America CEO Alain Leray, e-mail exchange to author, March 15, 2016.

${ }^{71}$ Margaret Urban Walker, Moral Repair: Reconstructing Moral Relations after Wrongdoing, 1st ed. (Cambridge, UK: Cambridge University Press, 2006).

${ }^{72}$ Carlos E. Sluzki, Donald C. Ransom, and Gregory Bateson, Double Bind: The Foundation of Communicational Approach to the Family, (New York: Psychological Corp., 1976).
} 
not the State. This had symbolic importance for them. Even if legally considered state-owned, some businesses may need to make contributions from their own coffers to provide victims the acknowledgement they require. Direct payment to survivors provides public admission of the harm and suggests it will not be repeated. If the State simply pays, it seems as if the complicit entity has made weaker promises about changing future behavior.

Finally, practitioners working in the aftermath of conflict will benefit by noting the public strength of victims' voices. U.S. based Holocaust survivors have political and economic power. U.S. public sympathy for the survivors enabled those challenging the company to win support in many states. This is often not the case. In most post-conflict contexts, survivors lack the power and voice to challenge large corporate entities, especially ones protected by the State. Victims of the 1965 genocide in Indonesia, for example, still have far less power and support for any claims. Some of those complicit in the genocide are still in power. The government has not formally recognized the genocide and innocent individuals are still barred from various government positions because of unsubstantiated claims that they were enemies of the state in the 1960s. Without public recognition of the victims, public sympathy cannot be easily expressed and pressure cannot be exerted. In contexts where victims lack strong public legitimacy and recognition, additional outside support and sponsorship might be required.

\section{The Genealogy of CSR: Primed for Human Rights Dialogues}

While the SNCF conflict became vitriolic, the relationship between business and development, peacebuilding and/or genocide prevention does not always have to be contentious. Corporate social responsibility (CSR) literature could help scholars find productive ways to engage these paradoxically ubiquitous yet hard to access entities. CSR, like transitional justice, emerged in the wake of WWII and now offers increasingly sophisticated frameworks that might be of interest to the field. After WWII, Howard Bowen and F. Earnest Johnson's "Social Responsibility of the Businessman" introduced the notion that business should improve American social and economic life basing his argument on Christian ethics. ${ }^{73}$ Until the late 1970s, however, the business community mocked corporate social responsibility. ${ }^{74}$ Milton Friedman sharply dismissed the field as anti-free market, claiming the concept placed an unfair burden on shareholders and executives. ${ }^{75}$ Moreover, Milton Friedman and others have expressed the concern that this turn towards corporate social responsibility is at odds with the shareholder primacy principle. ${ }^{76}$ This principle states, that companies must first and foremost operate on behalf of the shareholders. Friedman argued to place social good before the needs of the shareholder who invests in the company upends the whole free market mechanism. Many agreed with Friedman that CSR and most business ethics programs undercut the underpinnings of business. ${ }^{77}$

In spite of these concerns, by the late-1990s, the term became ubiquitous. Business scholars succeeded in developing models that more convincingly coupled profits with CSR. This peaked the interest of the business community, which faced an increasingly savvy and vocal consumer base that commented on everything from labor practices to the environmental impact of production. The development field also began engaging more deeply with corporations. The World Bank and United Nations authored CSR guidelines and dedicated departments to CSR. John Ruggie's work contributed to the formulation of UN Global Compact, inviting businesses into human rights

\footnotetext{
${ }^{73}$ Howard R. Bowen and F. Ernest Johnson, Social Responsibility of the Businessman (New York: Harper, 1953); Min-Dong Paul Lee, "A Review of the Theories of Corporate Social Responsibility: Its Evolutionary Path and the Road Ahead," International Journal of Management Reviews 10, no. 1 (2008),53-73.

${ }^{74}$ Steven D. Lydenberg, Corporations and the Public Interest: Guiding the Invisible Hand (San Francisco: Berrett-Koehler Publishers, 2005).

${ }^{75}$ Milton Friedman, Capitalism and Freedom (Chicago: University of Chicago Press, 1962).

${ }^{76}$ H. Jeff Smith. "The Shareholder v. Stakeholder Debate." MIT Sloan Management Review. Summer 2003.

${ }_{77}$ Scott Pegg, "An Emerging Market for the New Millennium: Transnational Corporations and Human Rights," Transnational Corporations and Human Rights 1, no. 17 (2003), 1-33. David Henderson, Misguided Virtue: False Notions of Corporate Social Responsibility (London: IEA, The Institute of Economic Affairs, 2001).
} 
dialogues with the United Nations. ${ }^{78}$

\section{Leveraging Corporate Interests}

CSR literature has proliferated beyond what this narrow introduction can fully present; however, the following section addresses several areas of special interest to the field genocide studies. The increased coupling of CSR with corporate financial performance (CFP) can assist those looking to gain leverage over companies operating in fragile post-conflict states. Threats to profit provide leverage in many Holocaust-related settlements. Stuart Eizenstat, for example, claims the French, German, Swiss, and Austrian banks settled WWII cases because shareholders found the case too costly, not because of conscience..$^{79}$ Playing hardball with corporations threatens their bottom line.

Reputation can also be used as leverage when working with corporations. Better understandings of reputation as a motivating factor could help practitioners skillfully include business in postconflict processes. The SNCF has used lobbying and other means to improve its poor image in the United States. Their opponents have done the same. The national and international press reports on its Holocaust history have severely challenged its reputation in the United States. This branding problem continues to vex and exhaust current executives who are wrapped up in the challenges of competing in an international market. For public companies, poor reputations can impact stock prices. Deborah Sparr argues that the proliferation of Internet has amplified the spotlight effect. People watch what companies do and hold them accountable for their actions impacting the behavior of companies ${ }^{80}$ Reputation is powerful. It is far easier to improve a neutral reputation than to turnaround a tarnished one. Just ask the SNCF.

\section{CSR and Genocide Studies: The Time is Right}

New CSR models offer some tantalizing places to start. Thomas Jones and Michael Porter advanced theories linking CSR and CFP through the now popularized stakeholder theory and the strategic philanthropy model..$^{81}$ Michael Porter believes that corporate aims do not inherently work against human rights. He argues that business has the moral obligation and commitment to develop healthy long-term business/society relationships that promote sustainability, transparency, and increase dialogues with citizens and activists. Other CSR theories could also provide a better bridge between market actors and genocide scholars and related disciplines. In 2002, Christine Parker advanced the idea of a democratically self-regulating "open corporation" as a means of advancing corporate accountability. This model promotes corporate independence while challenging the corporation to alter its internal norms and practices to avoid human rights violations. Corporations can do this, she believes, through "the marriage of management, democracy and law." ${ }^{82}$ This scholarship supports, in the words of Harvard University's Kennedy School CSR Initiative, the "public contribution of private enterprise." 83

Without this overlay with CSR, practitioners and scholars may feel as if they are trying to hold back giants with rubber bands or unravel hopelessly enormous knots of corruption. Natural synergies are possible by aligning CSR business interest models with the interests of peace, justice, truth, and freedom. At the same time, CSR would benefit from the overlay of genocide studies. The majority of this scholarship currently concerns itself with environmental issues and labor rights issues.

\footnotetext{
${ }^{78}$ The Global Compact invites businesses to join the United Nations in its promotion of human rights. Companies agree to adhere to certain principles and then the UN lists the companies as part of the compact.

${ }^{79}$ Stuart Eizenstat, Imperfect Justice: Looted Assets, Slave Labor, and the Unfinished Business of World War II (New York: Public Affairs, 2009).

${ }^{80}$ Debora L. Sparr, “The Spotlight and the Bottom Line: How Multinationals Export Human Rights," Foreign Affairs 77, no. 2 (1998), 7-12.

${ }^{81}$ Thomas M. Jones, "Instrumental Stakeholder Theory: A Synthesis of Ethics and Economics," Academy of Management Review 20, no. 2 (1995), 404-437; Michael E. Porter and Mark R. Kramer, "Strategy and Society," Harvard Business Review 84, no. 12 (2006), 78-92.

${ }^{82}$ Christine Parker, The Open Corporation: Effective Self-Regulation and Democracy (Cambridge, UK: Cambridge University Press, 2002), ix.

${ }^{83}$ Harvard Kennedy School Corporate Social Responsibility Initiative, 2013, Harvard University, accessed February 17, 2017, http://www.hks.harvard.edu/centers/mrcbg/programs/csri.
} 
The SNCF's involvement in restitution, commemoration, apologies, education, research, and dialogues point to many ways corporations can be involved. My dealings with the company, specifically, their openness to my research makes me think they might be willing to work on other related projects. Perhaps the company's efforts could turn towards addressing rising anti-Semitism and barbarism in France and throughout Europe.

\section{Conclusion}

Those who become most visible in the aftermath of atrocity are not necessarily the most culpable. This article emphasizes the cost of permitting market actors to escape accountability simply because their wealth and size may enable them to hide their activities. Legal lacunae also make accountability challenging Beyond accountability, market actors can become significant allies in failing societies, offering jobs, stability, and growth. By uniting CSR and genocide studies positions corporations can be seen as both part of the problem and part of the solution. Market actors are participants in a society and like everyone else play complicated roles as both perpetrator and even victim, often losing out when violence strikes. This is as much during the atrocity as after. Some harbor stolen funds or benefit from enrichment due to enslaved labor. Market actors can also fund post-conflict restitution and commemorative programs as well as provide needed jobs. To consider them solely perpetrator or victim betrays the truth of what happened and cuts of important areas of discourse.

The SNCF conflict demonstrates the ways in which some try to hold corporate actors accountable even seventy years into the aftermath. The legal lacuna that provides SNCF impunity provides insight into the kinds of mechanisms protecting others. Lobbying and legislation demonstrate the power of local voice in the United States. Yet, this can only occur in a government with legislators who are not protecting business interests and in a society where victims have voice. This is usually not the case. Most victims still struggle for public legitimacy or what the French call reconnaissance. This is true for Armenians, Indonesians, and many others. The market actors complicit in genocides will likely continue to march along unimpeded. The sidelining of market actors also blinds the field to allies. In South Sudan, for example, China's oil interests make them a partner for peace. They have sent troops to the UN Peacekeeping force and make public statements to demand a cessation of violent outbreaks.

Corporations are here to stay. Market actors become increasingly important. To neglect their role is to neglect the reality in which these atrocities take place.

\section{Bibliography}

Aguilar, Gaby Oré and Felipe Gómez Isa. Rethinking Transitions: Equality and Social Justice in Societies Emerging from Conflict. Cambridge, UK and Portland, OR: Intersentia, 2011.

Andrieu, Kora. “Dealing With a 'New' Grievance: Should Anticorruption Be Part of the Transitional Justice Agenda?" Journal of Human Rights 11, no. 4 (2012): 537-557. https://doi.org/10.1080/ 14754835.2012 .702471

Arbour, Louise. "Economic and Social Justice for Societies in Transition." New York University Journal of Law and Politics 40 (2007): 1-27.

Arthur, Paige. "How 'transitions' reshaped human rights: A conceptual history of transitional justice." Human Rights Quarterly 31, no. 2 (2009): 321-367. https://doi.org/10.1353/hrq.0.0069

Aukerman, Miriam J. "Extraordinary Evil, Ordinary Crime: A Framework for Understanding Transitional Justice." Harvard Human Rights Journal 15, (2002): 39-97.

Balasco, Lauren Marie. "The Transitions of Transitional Justice: Mapping the Waves From Promise to Practice." Journal of Human Rights 12, no. 2 (2013): 198-216. https://doi.org/10.1080/1475 $\underline{4835.2013 .784858}$

Baume, Maia de la. "French Railway Formally Apologizes to Holocaust Victims." The New York Times, January 25, 2011. Accessed February 17, 2017. http://www.nytimes.com/2011/01/26/ world/europe/26france.html? $\mathrm{r}=0$.

Bowen, Howard R. and F. Ernest Johnson. Social Responsibility of the Businessman. New York: Harper, 1953. 
Braithwaite, John. "Restorative Justice: Theories and Worries." Visiting Experts' Papers: 123 ${ }^{\text {rd }}$ International Senior Seminar, Resource Material Series vol. 63 (2004): 77-56.

Broch, Ludivine. Ordinary Workers, Vichy and the Holocaust: French Railwaymen and the Second World War. Cambridge, UK: Cambridge University Press, 2016. https://doi.org/10.1017/ CBO9781139600453

Broch, Ludivine,"Professionalism in the Final Solution: French Railway Workers and the Jewish Deportations, 1942-4." Contemporary European History 23, no. 3 (2014): 359-801. https://doi. org/10.1017/S0960777314000186

Brown, Graham, Corinne Caumartin, Arnim Langer, and Frances Stewart, "Addressing Horizontal Inequalities in Post-Conflict Reconstruction," in Rethinking Transitions: Equality and Social Justice in Societies Emerging from Conflict, edited by Gaby Oré Aguilar and Felipe Gomez Isa. Cambridge, UK and Portland, OR: Intersentia, 2011, 11-46.

Carranza, Ruben. "Plunder and Pain: Should Transitional Justice Engage with Corruption and Economic Crimes?" International Journal of Transitional Justice 2, no. 3 (2008): 310-330. https://doi.org/10.1093/ijtj/ijn023

Chatterjee, Pratap. "Chiquita Banana To Face Colombia Torture Claim." CorpWatch, March 30, 2012. Accessed February 17, 2017. http://www.corpwatch.org/article.php?id=15697.

Clément, René. La bataille du rail. Directed by René Clément. 1946. Paris: Coopérative Générale du Cinéma Français. Film.

Collier, Paul and The World Bank. "Breaking the Conflict Trap: Civil War and Development Policy." World Bank Publications, 2003.

"16 Février 2009 - Hoffman-Glemane." Le Conseil d'Etat et La Jurisdiction Administrative, September 28, 2015. Accessed February 17, 2017. http://www.conseil-etat.fr/Decisions-AvisPublications/Decisions/Les-decisions-les-plus-importantes-du-Conseil-d-Etat/16-fevrier2009-Hoffman-Glemane.

Dewey, John. "The Historic Background of Corporate Legal Personality." Yale Law Journal 35, (1925): 655-673. https://doi.org/10.2307/788782

DeWinter, Rebecca. "The Anti-Sweatshop Movement: Constructing Corporate Moral Agency in the Global Apparel Industry." Ethics \& International Affairs 15, no. 2 (2001): 99-115. https://doi.org/10.1111/j.1747-7093.2001.tb00361.x

Doig, Alan and Stephanie Mclvor. "Feature Review Corruption and its Control in the Developmental Context: An Analysis and Selective Review of the Literature." Third World Quarterly 20, no. 3 (1999): 657-676. https://doi.org/10.1080/01436599913749

Drexler, E.F. "Fatal Knowledge: The Social and Political Legacies of Collaboration and Betrayal in Timor-Leste." International Journal of Transitional Justice 7, no. 1 (2013): 74-94. https://doi.org/10.1093/ijti/ijs037

Drumbl, Mark. "Collective Violence and Individual Punishment: The Criminality of Mass Atrocity." Northwestern University Law Review Winter (2005): 538-610.

Durand, Paul. La SNCF pendant la guerre. Paris: Presses Universitaires de France, 1968.

Echlin, John. "Undercutting the Political Economy of Conflict Is Bosnia and Herzegovina: A Transitional Justice Approach to Prosecuting Systemic Economic Crimes." Columbia Journal of Transnational Law 48 (2009): 353-398.

Eizenstat, Stuart. Imperfect Justice: Looted Assets, Slave Labor, and the Unfinished Business of World War II. New York: Public Affairs, 2009.

Farmer, Paul. Pathologies of Power: Health, Human Rights, and the New War on the Poor. Berkeley: University of California Press, 2003.

Federman, Sarah. Aller Simple (One-Way Ticket) Corporate Accountability for Mass Atrocity: A Study of the French National Railroads. Diss. George Mason University, 2015.

Ferencz, Benjamin B. Less Than Slaves: Jewish Forced Labor and the Quest for Compensation. Cambridge: Harvard University Press, 1979.

Friedman, Milton. Capitalism and Freedom. Chicago: University of Chicago Press, 1962. From Words to Action, the Responsibility to Protect. The United States Holocaust Memorial Museum, 23 July 2013. 
Galtung, Johan. "Violence, Peace, and Peace Research," Journal of Peace Research 6, no. 3 (1969): 167191. https://doi.org/10.1177/002234336900600301

Golsan, Richard J. "Crimes-against-Humanity Trials in France and Their Historical and Legal Contexts: A Retrospective Look." In Atrocities on Trial: Historical Perspectives on the Politics of Prosecuting War Crimes, edited by Patricia Heberer and Jürgen Matthäus, 247-261. Lincoln and Washington, DC: University of Nebraska Press; Published in association with the United States Holocaust Memorial Museum, 2008.

Gomez, Manuel A. "The Global Chase: Seeking the Recognition and Enforcement of the Lago Agrio Judgment Outside of Ecuador." Stanford Journal of Complex Litigation 1, no. 199 (2013): 13-14.

Gready, Paul. The Era of Transitional Justice: The Aftermath of the Truth and Reconciliation Commission in South Africa and Beyond. London: Routledge, 2010.

Harvard Kennedy School Corporate Social Responsibility Initiative. Harvard University, 2013. Accessed February 17, 2017. http://www.hks.harvard.edu/centers/mrcbg/programs/csri.

Hayner, Priscilla B. Unspeakable Truths: Transitional Justice and the Challenge of Truth Commissions. New York: Routledge, 2010.

Heller, Kevin Jon. “Nuremberg Scholars Amicus Brief in Kiobel." Opinio Juris, December 23, 2011. Accessed February 17, 2017. http://opiniojuris.org/2011/12/23/nuremberg-scholars-amicusbrief-in-kiobel/.

Henderson, David. Misguided Virtue: False Notions of Corporate Social Responsibility. London: IEA, The Institute of Economic Affairs, 2001.

Hilberg, Raul. "German Railroads/Jewish Souls." Society 14, no. 1 (1976): 60-74. https://doi. org/10.1007/BF02694653

Jones, Thomas M. "Instrumental Stakeholder Theory: A Synthesis of Ethics and Economics." Academy of Management Review 20, no. 2 (1995): 404-437.

Klarsfeld, Arno. “La SNCF et les trains de la mort." Le Monde, June 3, 2006.

Lambourne, Wendy. "Transitional Justice and Peacebuilding after Mass Violence." International Journal of Transitional Justice 3, no. 1 (2009): 28-48. https://doi.org/10.1093/ijti/ijn037

LaPlante, Lisa J. "On the Indivisibility of Rights: Truth Commissions, Reparations, and the Right to Develop." Yale Human Rights \& Development Law Journal 10 (2007): 141-177.

Laufer, William S. "Corporate Bodies and Guilty Minds." Emory Law Journal 43 (1994): 648-730.

Lee, Min-Dong Paul. "A Review of the Theories of Corporate Social Responsibility: Its Evolutionary Path and the Road Ahead." International Journal of Management Reviews 10, no. 1 (2008): 53-73. https://doi.org/10.1111/j.1468-2370.2007.00226.x

Lipietz, Alain. La SNCF et la Shoah: le procès G. Lipietz contre État et SNCF: Essai. Paris: Les Petits Matins, 2011.

Lydenberg, Steven D. Corporations and the Public Interest: Guiding the Invisible Hand. San Francisco: Berrett-Koehler Publishers, 2005.

Marrus, Michael R. and Robert O. Paxton. Vichy France and the Jews. New York: Basic Books, 1981.

McEvoy, Kieran. "Beyond Legalism: Towards a Thicker Understanding of Transitional Justice." Journal of Law and Society 34, no. 4 (2007): 411-440. https://doi.org/10.1111/j.14676478.2007.00399.x

Miller, Zinaida. "Effects of Invisibility: In Search of the 'Economic' in Transitional Justice." International Journal of Transitional Justice 2, no. 3 (2008): 266-291. https://doi.org/10.1093/ ijti/ijn022

Minow, Martha. Between Vengeance and Forgiveness: Facing History after Genocide and Mass Violence. Boston: Beacon Press, 1999.

Muvingi, I. "Sitting on Powder Kegs: Socioeconomic Rights in Transitional Societies." International Journal of Transitional Justice 3, no. 2 (2009): 163-182. https://doi.org/10.1093/ijtj/ijp010

Nagy, Rosemary L. "The Scope and Bounds of Transitional Justice and the Canadian Truth and Reconciliation Commission." International Journal of Transitional Justice 7, no. 1 (2012): 52 73. https://doi.org/10.1093/iitj/ijs034

Olsen, Tricia D., Andrew G. Reiter, and Eric Wiebelhaus-Brahm. “Taking Stock: Transitional Justice and Market Effects in Latin America." Journal of Human Rights 10, no. 4 (2011): 521-543. https://doi.org/10.1080/14754835.2011.619411 
Ortega, Olga Martín. “Deadly Ventures? Multinational Corporations and Paramilitaries in Colombia." Revista Electrónica de Estudios Internacionales no. 16 (2008): 1-13.

Parker, Christine. The Open Corporation: Effective Self-Regulation and Democracy. Cambridge, UK: Cambridge University Press, 2002. https://doi.org/10.1017/CBO9780511550034

Paxton, Robert, Stanley Hoffman, and Claude Bertrand. Vichy France: old guard and new order, 194044. New York: Knopf, distributed by Random House, 1972.

Pegg, Scott. "An Emerging Market for the New Millennium: Transnational Corporations and Human Rights." In Transnational Corporations and Human Right, edited by Jedrzej George Frynas and Pegg Scott, 1-33. Houndmills, Basingstoke, Hampshire and New York: Palgrave, 2003. https://doi.org/10.1057/9781403937520 1

Polino, Marie-Noëlle. Association pour l'histoire des chemins de fer en France (AHICF). Une entreprise publique dans la guerre la SNCF 1939-1945. Paris, Assemblée Nationale: 21-22 Juin 2000. Paris: Presse Universitaires de France (PUF), 2001.

Porter, Michael E. Porter and Mark R. Kramer. "Strategy and Society." Harvard Business Review 84, no. 12 (2006): 78-92.

Ribeill, Georges. “Dossier SNCF et Déportations.” Historail 4 (2008): 34-87.

Roht-Arriaza, Naomi and Javier Mariezcurrena. Transitional Justice in the Twenty-first Century: Beyond Truth Versus Justice. Cambridge, UK and New York: Cambridge University Press, 2006. https://doi.org/10.1017/CBO9780511617911

Rousso, Henry and Arthur Goldhammer. The Vichy Syndrome: History and Memory in France since 1944. Harvard University Press, 1994.

Ruggie, John. "Guiding Principles on Business and Human Rights: Implementing the United Nations 'Protect, Respect, and Remedy' Framework." New York and Geneva: United Nations Human Rights, 2011.

Salmond, Sir John William and Patrick John Fitzgerald. Salmond on Jurisprudence. London: Sweet \& Maxwell, 1966.

Shaver, Katherine. “Maryland Lawmaker Says He Won't Jeopardize Purple Line Funding with Holocaust Bill." The Washington Post, March 11, 2014.

Shaw, Rosalind, Lars Waldorf, and Pierre Hazan. Localizing Transitional Justice: Interventions and Priorities after Mass Violence. Stanford: Stanford University Press, 2010.

Smith, H. Jeff. "The Shareholder v. Stakeholder Debate." MIT Sloan Management Review, July 15, 2003.

SNCF. “History and Memory: SNCF \& World War II." Paris: SNCF, 2012.

SNCF. Profile and Key Figures, 2013.

Sparr, Debora L. "The Spotlight and the Bottom Line: How Multinationals Export Human Rights," Foreign Affairs 77, no. 2, (1998): 7-12. https://doi.org/10.2307/20048784

Steinhardt, Ralph G. "Corporate Responsibility and the International Law of Human Rights: The New Lex Mercatoria." In Non-State Actors and Human Rights, ed Philip Alston. Oxford, UK and New York: Oxford University Press, 2005.

Toor, Amar. "The Holocaust's Legacy Threatens One Company's US Rail Projects." The Verge, March 7, 2014.

United Convention Against Corruption, UN General Assembly Resolution A/RES/58/4. Implemented 14 December 2005.

Van der Merwe, Hugo and Audrey R Chapman. Assessing the Impact of Transitional Justice: Challenges for Empirical Research. Washington, DC: United States Institute of Peace, 2008.

Waldorf, Lars. "Anticipating the Past: Transitional Justice and Socio-Economic Wrongs." Social \& Legal Studies 21, no. 2 (2012): 171-186. https://doi.org/10.1177/0964663911435827

Walker, Margaret Urban. Moral Repair: Reconstructing Moral Relations after Wrongdoing. $1^{\text {st }}$ edition. Cambridge, UK and New York: Cambridge University Press, 2006. https://doi.org/10.1017/ CBO9780511618024

War, Glenn T and Gregory P. Noone, "The Culture of Corruption in the Postconflict and Developing World." In Imagine Coexistence: Restoring Humanity after Violent Ethnic Conflict, edited by Antonia Handler Chayes, Martha Minow, and Program on Negotiation at Harvard Law School, 191-209. San Francisco: Jossey-Bass, 2003. 
Wetzel, Johannes. “'The Past Doesn't Pass' - A German Look At France's Nazi Collaboration.” World Crunch, October 15, 2012.

Wieviorka, Annette. “La SNCF, la Shoah et le Juge” L'Histoire. 316 (January 2007): 89-99. 